\title{
Atmospheric reactive nitrogen concentrations at ten sites with contrasting land use in an arid region of central Asia
}

\author{
K. H. Li ${ }^{1,2, *}$, W. Song ${ }^{1,2, *}$, X. J. Liu ${ }^{3}$, J. L. Shen ${ }^{4}$, X. S. Luo ${ }^{3}$, X. Q. Sui ${ }^{5}$, B. Liu ${ }^{1,6}$, Y. K. Hu ${ }^{1}$, P. Christie ${ }^{3,7}$, and \\ C. Y. $\operatorname{Tian}^{1}$ \\ ${ }^{1}$ State Key Laboratory of Desert and Oasis Ecology, Xinjiang Institute of Ecology and Geography, \\ Chinese Academy of Sciences, Urumqi 830011, China \\ ${ }^{2}$ Graduate University of Chinese Academy of Science, Beijing 100039, China \\ ${ }^{3}$ College of Resources and Environmental Sciences, China Agricultural University, Beijing 100193, China \\ ${ }^{4}$ Institute of Subtropical Agriculture, Chinese Academy of Sciences, Changsha 410125, China \\ ${ }^{5}$ College of Grassland and Environmental Sciences, Xinjiang Agricultural University, Urumqi 830052, China \\ ${ }^{6}$ Cele National Station of Observation and Research for Desert-Grassland Ecosystems in Xinjiang, Cele 848300, China \\ ${ }^{7}$ Agri-Environment Branch, Agri-Food and Biosciences Institute, Belfast BT9 5PX, UK \\ *These authors contributed equally to this work.
}

Correspondence to: X. J. Liu (liu13500@yahoo.com.cn) and C. Y. Tian (tianchy@ms.xjb.ac.cn)

Received: 30 April 2012 - Published in Biogeosciences Discuss.: 6 June 2012

Revised: 5 September 2012 - Accepted: 5 September 2012 - Published: 18 October 2012

\begin{abstract}
Atmospheric concentrations of reactive nitrogen $\left(\mathrm{N}_{\mathrm{r}}\right)$ species from 2009 to 2011 are reported for ten sites in Xinjiang, China, an arid region of central Asia. Concentrations of $\mathrm{NH}_{3}, \mathrm{NO}_{2}$, particulate ammonium and nitrate $\left(p \mathrm{NH}_{4}^{+}\right.$and $\left.p \mathrm{NO}_{3}^{-}\right)$showed large spatial and seasonal variation and averaged 7.71, 9.68, 1.81 and $1.13 \mu \mathrm{g} \mathrm{N} \mathrm{m}^{-3}$, and $\mathrm{PM}_{10}$ concentrations averaged $249.2 \mu \mathrm{g} \mathrm{m}^{-3}$ across all sites. Lower $\mathrm{NH}_{3}$ concentrations and higher $\mathrm{NO}_{2}, p \mathrm{NH}_{4}^{+}$and $p \mathrm{NO}_{3}^{-}$concentrations were found in winter, reflecting serious air pollution due to domestic heating in winter and other anthropogenic sources such as increased emissions from motor traffic and industry. The increasing order of total concentrations of $\mathrm{N}_{\mathrm{r}}$ species was alpine grassland; desert, desertoasis ecotone; desert in an oasis; farmland; suburban and urban ecosystems. Lower ratios of secondary particles $\left(\mathrm{NH}_{4}^{+}\right.$ and $\mathrm{NO}_{3}^{-}$) were found in the desert and desert-oasis ecotone, while urban and suburban areas had higher ratios, which implied that anthropogenic activities have greatly influenced local air quality and must be controlled.
\end{abstract}

\section{Introduction}

Anthropogenic activities have greatly accelerated the emissions of reactive nitrogen $\left(\mathrm{N}_{\mathrm{r}}\right)$ species worldwide (Galloway et al., 2008), with a consequent increase in atmospheric deposition of $\mathrm{N}_{\mathrm{r}}$ species. Elevated $\mathrm{N}$ deposition/addition may lead to eutrophication (Vitousek et al., 1997; Liu et al., 2011), declining biodiversity (Phoenix et al., 2006; Clark and Tilman, 2008; Song et al., 2011), soil acidification (Guo et al., 2010) and increased $\mathrm{N}_{2} \mathrm{O}$ emission (Li et al., 2012a, b) in aquatic and terrestrial ecosystems. $\mathrm{N}_{\mathrm{r}}$ species emissions have resulted in profound deterioration of local air quality (Chan and Yao, 2008; Kulshrestha et al., 2009; Shen et al., 2011a). $\mathrm{N}_{\mathrm{r}}$ deposition has therefore become an important public concern (Liu et al., 2011; Sutton et al., 2011).

Arid and semi-arid regions account for $47 \%$ of the global land area and play a significant role in global N cycling. Xinjiang Uyghur Autonomous Region is located at the center of the arid and semi-arid regions of central Asia and is one of the main source areas of Asian dust, which can be transported from central Asia to the Pacific Ocean, and occasionally to the west coast of the United States (Li et al., 2008). Rapid economic development has led to significant increases in the combustion of fossil fuels by industry, power plants 
and vehicles in Xinjiang since 2000, with rates of consumption of diesel oil, crude oil, raw coal and coke increasing by 12, 27, 68 and $92 \%$, respectively (Mamtimin and Meixner, 2011). In addition, $N$ fertilizer application has also increased steadily since the 1980s due to the expansion of cotton and cereal/fruit/vegetable production in Xinjiang. Increasing atmospheric $\mathrm{N}_{\mathrm{r}}$ pollution would therefore be expected in this region. On the other hand, $\mathrm{N}$ limitation of plant growth often occurs in arid and semi-arid regions and atmospheric $\mathrm{N}_{\mathrm{r}}$ deposition may act as an important source of plant nutrients (Liu et al., 2010). Thus, $\mathrm{N}$ inputs from $\mathrm{N}_{\mathrm{r}}$ deposition can have an important $\mathrm{N}$ fertilizer effect in arid and semi-arid regions (Bai et al., 2010; Song et al., 2012). However, very little is known about the influence of air pollutants and the dynamics of $\mathrm{N}_{\mathrm{r}}$ concentrations in the arid regions of China. The current study attempted to determine the spatial and seasonal characteristics of atmospheric $\mathrm{N}_{\mathrm{r}}$ pollution in different ecosystems within the arid Xinjiang region of northwest China.

\section{Materials and methods}

\subsection{Monitoring sites}

The study was carried out at ten sites in the Xinjiang arid region in northwestern China. Site BYB is at Bayinbuluk Grassland Ecosystem Research Station, Chinese Academy of Sciences (CAS), which is located in the southern Tian Shan Mountains (3000-4500 m a.s.l.) of central Asia, covering a total area of approximately $23000 \mathrm{~km}^{2}$. Site TZZ is at the Taklimakan Desert Research Station, CAS, in the center of the Taklimakan Desert. The Taklimakan Desert is in the arid center of Eurasia and covers a total area of $337600 \mathrm{~km}^{2}$. Site CLZ is located at Cele Desert Research Station, CAS, near the southern fringe of the Taklimakan Desert, one of the three most extreme arid zones in the world. Site TLF denotes Turpan Eremophyte Botanic Garden, CAS; its main landform is the improved shifting sand land in the hinterland of the Turpan Basin. Site FKZ is at Fukang Research Station for Desert Ecology, CAS, which is situated at the southern fringe of the Gurbantunggut Desert in central Asia. Cotton is the most important cash crop in the region, and fertilizer is usually applied as $\left(\mathrm{NH}_{4}\right)_{2} \mathrm{HPO}_{4}$ at $450 \mathrm{~kg} \mathrm{ha}^{-1}$ and mixed in the top $20 \mathrm{~cm}$ of the soil profile before sowing (Tang et al., 2010). Site AKS is located at Aksu Research Station for Farmland Ecosystems, CAS, which is located at the northern fringe of the Tarim Basin and near downstream Aksu River, a tributary of the Tarim River. This is a large and nationally important cotton production area that is characterized by dramatic watercourse changes and high agricultural water consumption. Site YPH is located at an experimental farm of Xinjiang Academy of Agricultural Sciences and is a typical farmland monitoring site where wheat and maize are the main crops. Site BTH is an experiment of Xinjiang Academy of Agricultural Sciences and is a typical farmland

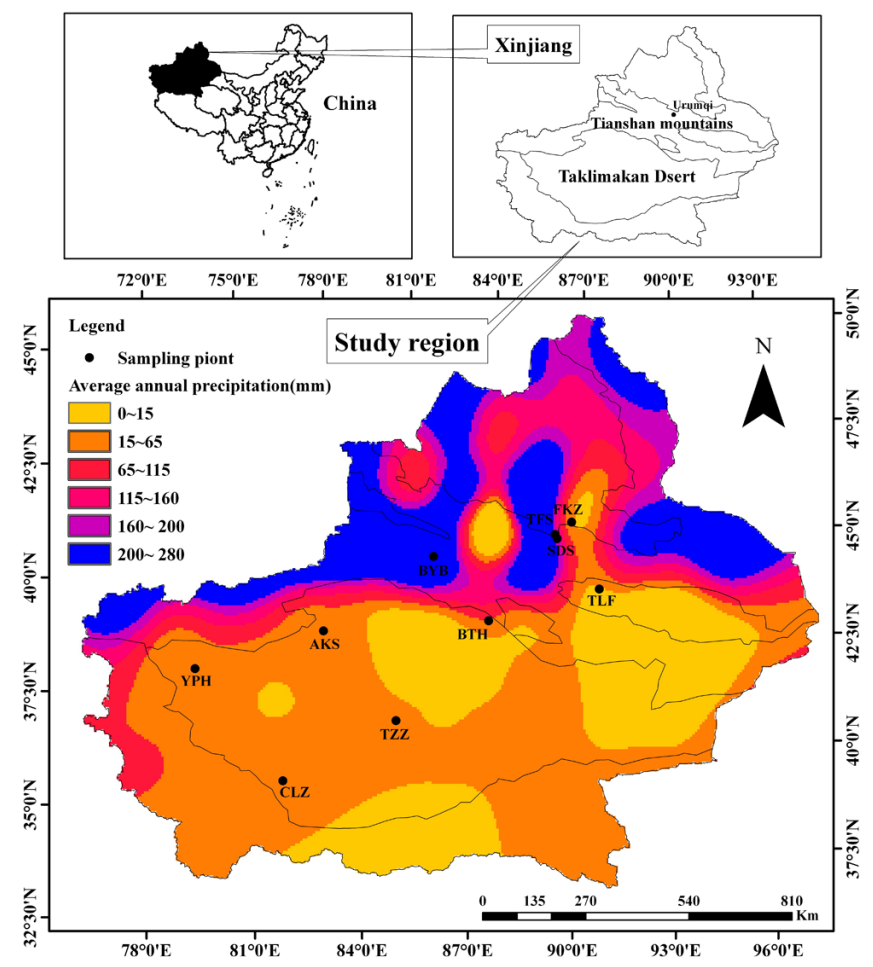

Fig. 1. Distribution of the ten monitoring sites in the Xinjiang arid region of northwest China.

monitoring site adjacent to the west of Kongque River where cotton is also an important regional crop. Site TFS is located at an experimental farm of Xinjiang Academy of Agricultural Sciences and is a typical suburban monitoring site. Site SDS is located in Urumqi city, the most inland city in the world about $2500 \mathrm{~km}$ from the Arctic, Indian and Pacific Oceans. It is surrounded by the Tian Shan Mountains to the north, east and west. The city covers a total area of approximately $140 \mathrm{~km}^{2}$ with a population of 2.2 million and is a typical urban monitoring site. Sites SDS and TFS are only about $11 \mathrm{~km}$ apart. Additional characteristics of the sites are shown in Table 1 and Fig. 1.

\subsection{Sampling procedure and sample analysis}

$\mathrm{NH}_{3}$ and $\mathrm{NO}_{2}$ samples were collected using Radiello passive samplers (Aquaria Italy, Trident Equipments Pvt. Ltd., Mumbai, India). At each site three $\mathrm{NH}_{3}$ and three $\mathrm{NO}_{2}$ samplers were exposed during each measurement period inside a PVC shelter ( $2 \mathrm{~m}$ above the ground) to protect the samplers from precipitation and direct sunlight. $\mathrm{NH}_{3}$ and $\mathrm{NO}_{2}$ concentrations were measured monthly by exposing the samplers for two weeks in the middle of the month. After sampling, absorption cartridges of the passive samplers were placed in airtight plastic tubes and stored in a refrigerator at $4{ }^{\circ} \mathrm{C}$ until analysis with an automated, segmented continuous 
Table 1. Characteristics of the ten monitoring sites in the Xinjiang arid region of northwest China.

\begin{tabular}{lllllll}
\hline Site No. & Site Name & Land Use Type & Latitude (N) & Longitude (E) & Altitude (m) & Sampling Period \\
\hline 1 & BYB (Bayinbuluk) & Alpine grassland & $42^{\circ} 53.079^{\prime}$ & $83^{\circ} 42.528^{\prime}$ & 2470 & Sep 2009-Sep 2011 \\
2 & TZZ (Tazhong) & Desert & $38^{\circ} 58.317^{\prime}$ & $83^{\circ} 39.548^{\prime}$ & 1095 & Apr 2011-Nov 2011 \\
3 & CLZ (Cele) & Desert-oasis ecotone & $37^{\circ} 00.938^{\prime}$ & $80^{\circ} 43.749^{\prime}$ & 1363 & Apr 2011-Nov 2011 \\
4 & TLF (Tulufan) & Desert in an oasis & $42^{\circ} 51.245^{\prime}$ & $89^{\circ} 11.424^{\prime}$ & -106 & Aug 2009-Sep 2011 \\
5 & FKZ (Fukang) & Farmland near a desert & $44^{\circ} 17.574^{\prime}$ & $87^{\circ} 56.025^{\prime}$ & 455 & Aug 2009-Sep 2011 \\
6 & AKS (Aksu) & Farmland & $40^{\circ} 37.107^{\prime}$ & $80^{\circ} 49.722^{\prime}$ & 1019 & Apr 2011-Nov 2011 \\
7 & YPH (Yuepuhu) & Farmland & $39^{\circ} 00.187^{\prime}$ & $77^{\circ} 16.057^{\prime}$ & 1175 & Apr 2011-Nov 2011 \\
8 & BTH (Baotouhu) & Farmland & $41^{\circ} 40.620^{\prime}$ & $85^{\circ} 51.650^{\prime}$ & 893 & Apr 2011-Nov 2011 \\
9 & TFS (Tufeisuo) & Suburban & $43^{\circ} 56.482^{\prime}$ & $87^{\circ} 28.240^{\prime}$ & 576 & Aug 2009-Oct 2011 \\
10 & SDS (Shengdisuo) & Urban & $43^{\circ} 51.182^{\prime}$ & $87^{\circ} 33.747^{\prime}$ & 775 & Aug 2009-Oct 2011 \\
\hline
\end{tabular}

flow analyzer (Seal AA3, Norderstedt, Germany) within two months. Detailed information about the passive samplers has been provided by Shen et al. (2009). Airborne $\mathrm{PM}_{10}$ particles (particulate matter whose aerodynamic equivalent diameter is $<10 \mu \mathrm{m}$ ) were sampled using a particulate sampler (BGI, Omni, Waltham, MA) with a flow rate of $51 \mathrm{~min}^{-1}$, and 7-10 daily samples of $\mathrm{PM}_{10}$ were collected at each site during each month. The sampler was placed about $2 \mathrm{~m}$ above the ground and ran for $24 \mathrm{~h}$ to obtain a particulate matter sample on $47 \mathrm{~mm}$ quartz filters (Whatman, Maidstone, UK). Before and after sampling, each filter was conditioned for at least $24 \mathrm{~h}$ inside a chamber at a relative humidity of $50 \%$ and a temperature of $25^{\circ} \mathrm{C}$, and then weighed (Sartorius, Göttingen, Germany; precision $10 \mu \mathrm{g}$ ). $\mathrm{PM}_{10}$ mass concentrations were determined from the mass difference and the sampled air volume. Each sampling filter was extracted with $10 \mathrm{ml}$ deionized water by ultrasonication for $30 \mathrm{~min}$, and the extract solution was filtered through a syringe filter $(0.45 \mathrm{~mm}$, Tengda Inc., Tianjin, China) and stored in a refrigerator. Chemical analysis of $\mathrm{PM}_{10}$ was conducted within two months. Ammonium and nitrate in $\mathrm{PM}_{10}\left(p \mathrm{NH}_{4}^{+}\right.$and $\left.p \mathrm{NO}_{3}^{-}\right)$were measured by continuous flow analyzer (Seal AA3). Monthly mean air temperature, precipitation, wind speed and relative humidity from August 2009 to November 2011 at all sites except TFS and YPH are shown in Fig. 2.

\subsection{Statistical analysis}

Values of $\mathrm{NH}_{3}, \mathrm{NO}_{2}, \mathrm{PM}_{10}, p \mathrm{NH}_{4}^{+}$and $p \mathrm{NO}_{3}^{-}$concentrations each month at all sites are means \pm standard errors (s.e.). All statistical analyses (Pearson correlation analysis and one-way analysis of variance) were performed using the SPSS 13.0 statistical package (SPSS Inc., Chicago, IL).

\section{Results}

\subsection{Spatial variation of $\mathrm{N}_{\mathrm{r}}$ concentrations}

Spatial variation in annual average $\mathrm{N}_{\mathrm{r}}$ concentrations is shown in Table 2 and Fig. 3. Annual average $\mathrm{NH}_{3}$ con-
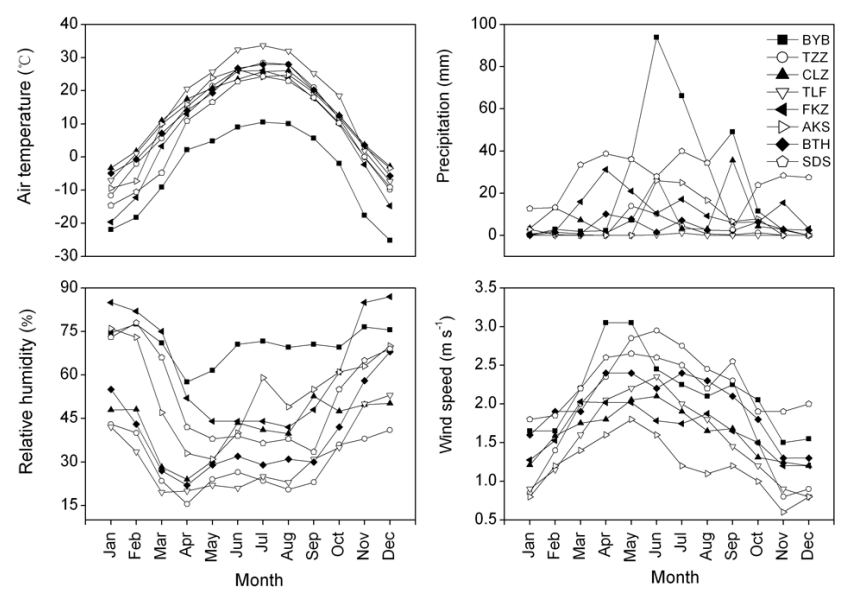

Fig. 2. Air temperature, precipitation, wind speed and relative humidity from August 2009 to November 2011 at the monitoring sites.

centrations ranged from 1.72 to $14.2 \mu \mathrm{g} \mathrm{N} \mathrm{m}^{-3}$ at the ten sites, with an overall average value of $7.71 \mu \mathrm{g} \mathrm{N} \mathrm{m}^{-3}$. The $\mathrm{NH}_{3}$ concentrations followed the following increasing sequence: alpine grassland (BYB, $1.72 \mu \mathrm{g} \mathrm{N} \mathrm{m}^{-3}$ ) and desert (TZZ, $2.61 \mu \mathrm{g} \mathrm{N} \mathrm{m}^{-3}$ ); desert in oasis (TLF, $5.61 \mu \mathrm{g} \mathrm{N} \mathrm{m}^{-3}$ ), desert-oasis ecotone (CLZ, $6.23 \mu \mathrm{g} \mathrm{N} \mathrm{m}^{-3}$ ), farmland near desert (FKZ, $6.29 \mu \mathrm{g} \mathrm{N} \mathrm{m}^{-3}$; AKS, 7.21 $\mu \mathrm{g} \mathrm{N} \mathrm{m}^{-3}$ ) and urban (SDS, $7.92 \mu \mathrm{g} \mathrm{N} \mathrm{m}^{-3}$ ); farmland near suburban (TFS, $11.4 \mu \mathrm{g} \mathrm{N} \mathrm{m}^{-3}$ ) and farmland (BTH, $13.9 \mu \mathrm{g} \mathrm{N} \mathrm{m}^{-3}$; YPH, $14.2 \mu \mathrm{g} \mathrm{N} \mathrm{m}^{-3}$ ). Annual average $\mathrm{NO}_{2}$ concentrations ranged from 1.01 to $30.1 \mu \mathrm{g} \mathrm{N} \mathrm{m}^{-3}$, with an overall mean value of $9.68 \mu \mathrm{g} \mathrm{N} \mathrm{m}{ }^{-3}$. The annual average $\mathrm{PM}_{10}$ concentrations ranged from 22.5 to $591.8 \mathrm{\mu g} \mathrm{m}^{-3}$, and overall averaged $249.2 \mu \mathrm{g} \mathrm{m}^{-3}$. The annual mean $p \mathrm{NH}_{4}^{+}$concentrations at the ten sites ranged from 0.08 to $6.6 \mu \mathrm{g} \mathrm{N} \mathrm{m}^{-3}\left(1.81 \mu \mathrm{g} \mathrm{N} \mathrm{m}{ }^{-3}\right.$ on average), and the annual average $p \mathrm{NO}_{3}^{-}$concentrations ranged from 0.22 to $2.58 \mu \mathrm{g} \mathrm{N} \mathrm{m}^{-3}\left(1.13 \mu \mathrm{g} \mathrm{N} \mathrm{m}^{-3}\right.$ on average). Total concentrations of reactive nitrogen species were, respectively, 3.09, 6.81, 11.9, 14.3, 15.3, 19.1, 22.8, 26.2, 36.7 and $47.0 \mu \mathrm{g} \mathrm{m}^{-3}$ at BYB, TZZ, CLZ, AKS, TLF, 
Table 2. Concentrations of $\mathrm{PM}_{10}, p \mathrm{NH}_{4}^{+}$and $p \mathrm{NO}_{3}^{-}$in $\mathrm{PM}_{10}, \mathrm{NH}_{3}, \mathrm{NO}_{2}$ and ratios of concentrations of secondary particles $\left(p \mathrm{NH}_{4}^{+}\right.$plus $p \mathrm{NO}_{3}^{-}$) to $\mathrm{PM}_{10}$.

\begin{tabular}{lrrrrrr}
\hline Site & $\begin{array}{r}\mathrm{PM}_{10} \\
\left(\mu \mathrm{g} \mathrm{m}^{-3}\right)\end{array}$ & $\begin{array}{r}\mathrm{pNH}_{4}^{+} \\
\left(\mu \mathrm{N} \mathrm{m}^{-3}\right)\end{array}$ & $\begin{array}{r}\mathrm{NO}_{3}^{-} \\
\left(\mu \mathrm{N} \mathrm{m}^{-3}\right)\end{array}$ & $\begin{array}{r}\mathrm{NH}_{3} \\
\left(\mu \mathrm{N} \mathrm{m}^{-3}\right)\end{array}$ & $\begin{array}{r}\mathrm{NO}_{2} \\
\left(\mu \mathrm{N} \mathrm{m}^{-3}\right)\end{array}$ & $\begin{array}{r}\text { Ratio } \\
(\%)\end{array}$ \\
\hline BYB & $22.5^{\mathrm{a}}$ & $0.18^{\mathrm{a}}$ & $0.96^{\mathrm{a}}$ & $1.72^{\mathrm{a}}$ & $1.01^{\mathrm{a}}$ & 5.07 \\
$\mathrm{TZZ}$ & $498.0^{\mathrm{c}}$ & $0.11^{\mathrm{a}}$ & $1.65^{\mathrm{ab}}$ & $2.61^{\mathrm{ab}}$ & $3.74^{\mathrm{b}}$ & 0.35 \\
$\mathrm{CLZ}$ & $591.8^{\mathrm{c}}$ & $0.76^{\mathrm{ab}}$ & $2.99^{\mathrm{b}}$ & $6.23^{\mathrm{bc}}$ & $4.39^{\mathrm{bc}}$ & 0.63 \\
$\mathrm{TLF}$ & $237.0^{\mathrm{bc}}$ & $1.51^{\mathrm{b}}$ & $5.18^{\mathrm{bc}}$ & $7.21^{\mathrm{b}}$ & $6.69^{\mathrm{bc}}$ & 2.82 \\
$\mathrm{FKZ}$ & $80.9^{\mathrm{b}}$ & $4.17^{\mathrm{b}}$ & $6.80^{\mathrm{bc}}$ & $5.61^{\mathrm{b}}$ & $7.31^{\mathrm{c}}$ & 13.55 \\
$\mathrm{AKS}$ & $229.2^{\mathrm{bc}}$ & $0.14^{\mathrm{a}}$ & $1.43^{\mathrm{a}}$ & $6.29^{\mathrm{bc}}$ & $7.98^{\mathrm{bc}}$ & 0.68 \\
$\mathrm{YPH}$ & $265.4^{\mathrm{bc}}$ & $0.76^{\mathrm{ab}}$ & $3.06^{\mathrm{b}}$ & $14.19^{\mathrm{c}}$ & $7.32^{\mathrm{c}}$ & 1.44 \\
$\mathrm{BTH}$ & $189.7^{\mathrm{bc}}$ & $0.95^{\mathrm{ab}}$ & $4.43^{\mathrm{bc}}$ & $13.90^{\mathrm{c}}$ & $10.55^{\mathrm{cd}}$ & 2.84 \\
$\mathrm{TFS}$ & $211.3^{\mathrm{bc}}$ & $6.38^{\mathrm{b}}$ & $11.21^{\mathrm{c}}$ & $11.44^{\mathrm{c}}$ & $17.72^{\mathrm{d}}$ & 8.33 \\
SDS & $166.3^{\mathrm{bc}}$ & $8.23^{\mathrm{b}}$ & $11.24^{\mathrm{c}}$ & $7.92^{\mathrm{bc}}$ & $30.07^{\mathrm{d}}$ & 11.70 \\
\hline
\end{tabular}

Values in a column without the same letters are significantly different at $p<0.05$. Ratio denotes $\left(p \mathrm{NO}_{3}^{-}+p \mathrm{NH}_{4}^{+}\right)$ concentrations as a percentage of $\mathrm{PM}_{10}$.

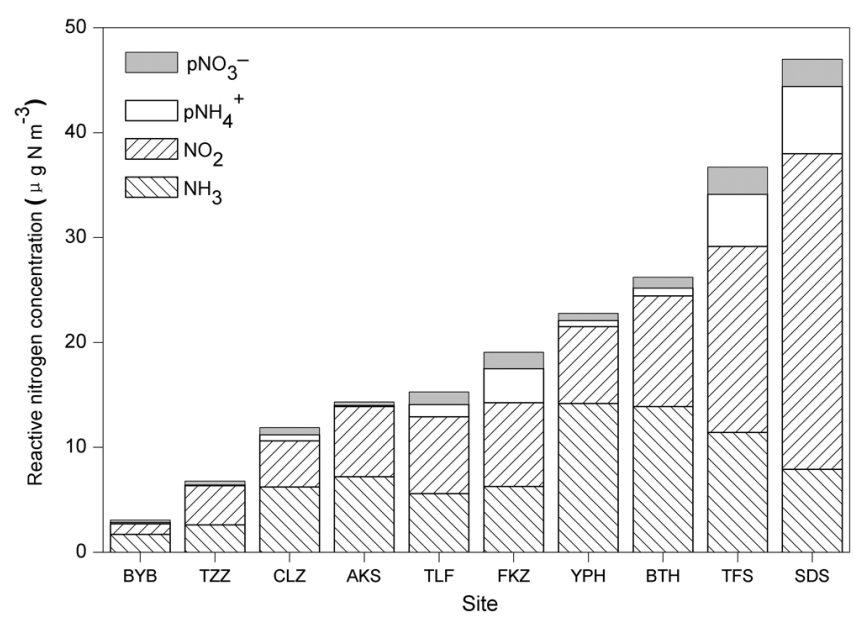

Fig. 3. Total annual average concentrations of reactive nitrogen species at the ten sites.

YPH, BTH, FKZ, TFS and SDS sites (Fig. 3), indicating significant differences among these monitoring sites (Table 2).

\subsection{Seasonal variation in $\mathrm{N}_{\mathrm{r}}$ concentrations}

$\mathrm{NH}_{3}$ exhibited distinct and significant temporal variation, with lowest concentrations in winter compared to in spring, summer or autumn (Fig. 4a). Monthly mean concentrations measured for $\mathrm{NH}_{3}$ and $\mathrm{NO}_{2}$ are given in Fig. $4 \mathrm{a}$ and $\mathrm{c}$, and the values ranged from 0.58 to 21.7 and 0.29 to $57.2 \mu \mathrm{g} \mathrm{N} \mathrm{m}^{-3}$ across all sites. In contrast to $\mathrm{NH}_{3}$, high monthly mean $\mathrm{NO}_{2}$ concentrations were found in winter (except site BYB). Monthly mean $\mathrm{PM}_{10}$ concentrations ranged from 3.06 to $876.2 \mu \mathrm{g} \mathrm{m}^{-3}$, and $\mathrm{PM}_{10}$ concentrations reached their maximum values in April at TZZ $\left(876.2 \mu \mathrm{g} \mathrm{m}^{-3}\right)$ and CLZ (852.7 $\mu \mathrm{g} \mathrm{m}^{-3}$ ) (Fig. 4e). $\mathrm{PM}_{10}$ concentrations were higher in winter and spring than in summer or autumn (except site BYB). Monthly mean $\mathrm{NH}_{4}^{+}$concentrations in $\mathrm{PM}_{10}\left(p \mathrm{NH}_{4}^{+}\right)$ ranged from 0.02 to $25.8 \mu \mathrm{g} \mathrm{N} \mathrm{m}^{-3}$, and $p \mathrm{NH}_{4}^{+}$concentrations peaked in winter with lower values in summer across almost all sites (Fig. 4b). Monthly mean particulate concentrations of $\mathrm{NO}_{3}^{-}$in $\mathrm{PM}_{10}\left(p \mathrm{NO}_{3}^{-}\right)$ranged from 0.02 to $11.1 \mu \mathrm{g} \mathrm{N} \mathrm{m}^{-3}$, and were higher in winter than in spring, summer or autumn (Fig. 4d).

\subsection{Mass concentrations of inorganic $\mathbf{N}$ ions in $\mathbf{P M}_{10}$}

Mass concentrations of $\mathrm{PM}_{10}$ and particulate $\mathrm{NH}_{4}^{+}$and $\mathrm{NO}_{3}^{-}$ in $\mathrm{PM}_{10}\left(p \mathrm{NH}_{4}^{+}\right.$and $\left.p \mathrm{NO}_{3}^{-}\right)$at the ten sites are shown in Table 2. Mean concentrations of $p \mathrm{NH}_{4}^{+}$and $p \mathrm{NO}_{3}^{-}$in $\mathrm{PM}_{10}$ ranged from 0.18 to $8.23 \mu \mathrm{g} \mathrm{m}^{-3}$ and from 0.96 to $11.2 \mu \mathrm{g} \mathrm{m}^{-3}$, and the concentrations of $p \mathrm{NH}_{4}^{+}$and $p \mathrm{NO}_{3}^{-}$in $\mathrm{PM}_{10}$ accounted for $0.8-5.2$ and $0.3-8.4 \%$ of $\mathrm{PM}_{10}$ across all sites. Concentrations of total inorganic $\mathrm{N}$ ions $\left(p \mathrm{NH}_{4}^{+}\right.$and $p \mathrm{NO}_{3}^{-}$) in $\mathrm{PM}_{10}$ accounted for $0.35-13.6 \%$ of $\mathrm{PM}_{10}$ across the ten sampling sites.

\subsection{Correlations between various $\mathrm{N}_{\mathrm{r}}$ species and effects of environmental factors on atmospheric $\mathrm{N}_{\mathbf{r}}$ concentrations}

Correlations between various atmospheric $\mathrm{N}_{\mathrm{r}}$ species concentrations across the ten sites are shown in Fig. 5. $\mathrm{NO}_{2}$ concentrations were significantly and positively correlated with $p \mathrm{NH}_{4}^{+}$(Fig. 5a), $p \mathrm{NO}_{3}^{-}$(Fig. 5b) and $\mathrm{NH}_{3}$ (Fig. 5c). Although no significant correlation was found between $\mathrm{NH}_{3}$ and $p \mathrm{NO}_{3}^{-}$concentrations (Fig. $5 \mathrm{~d}$ ), $p \mathrm{NH}_{4}^{+}$was significantly and negatively correlated with $\mathrm{NH}_{3}$ (Fig. 5e) and positively correlated with $\mathrm{NO}_{3}^{-}$(Fig. 5f). These positive or negative correlations reflected the complicated interactions between these $\mathrm{N}_{\mathrm{r}}$ species, in particular the transformations between 

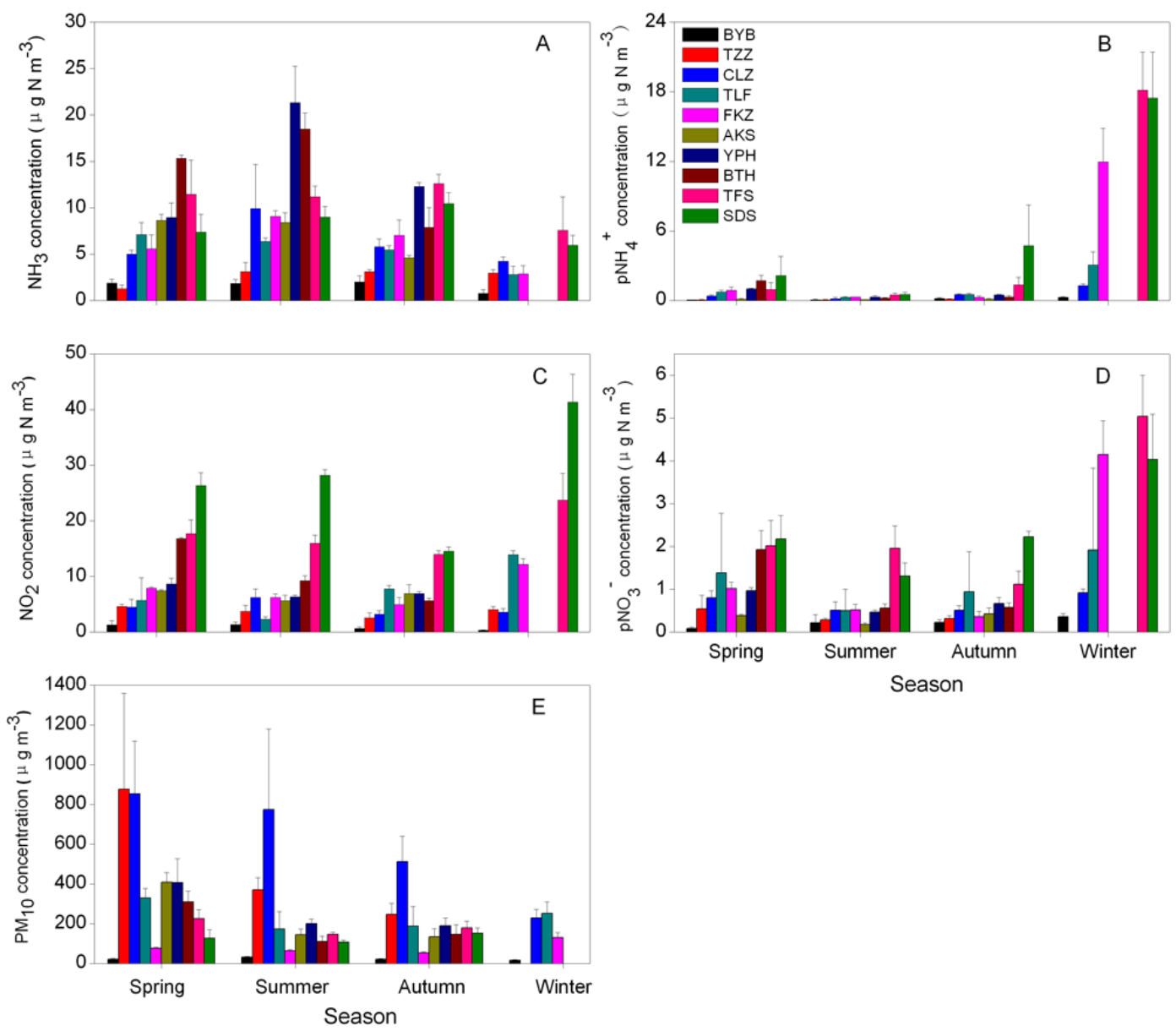

Fig. 4. Seasonal concentrations of $(\mathbf{A}) \mathrm{NH}_{3}$, (B) $p \mathrm{NH}_{4}^{+}$, (C) $\mathrm{NO}_{2}$, (D) $p \mathrm{NO}_{3}^{-}$and (E) $\mathrm{PM}_{10}$ at the ten sites. Spring, summer, autumn and winter denote the periods from December to February, March to May, June to August, and September to November, respectively.

gaseous $\mathrm{N}_{\mathrm{r}}$ species $\left(\mathrm{NH}_{3}\right.$ and $\left.\mathrm{NO}_{2}\right)$ and secondary particles (e.g. $p \mathrm{NH}_{4}^{+}$and $p \mathrm{NO}_{3}^{-}$).

The effects of environmental factors on atmospheric $\mathrm{N}_{\mathrm{r}}$ concentrations and $\mathrm{PM}_{10}$ are shown in Fig. 6. Both $p \mathrm{NH}_{4}^{+}$and $p \mathrm{NO}_{3}^{-}$concentrations showed significant negative correlations with air temperature and positive correlations with relative humidity (Fig. 6a-d). $\mathrm{PM}_{10}$ concentrations showed significant negative correlations with relative humidity (Fig. 6e). $\mathrm{NH}_{3}$ concentration showed significant positive correlations with air temperature (Fig. 6f) and wind speed (Fig. 6g) and negative correlations with relative humidity (Fig. 6h). No significant correlations were found between $\mathrm{NO}_{2}$ concentrations and environmental factors (data not shown).

\section{Discussion}

\subsection{Concentrations of $\mathrm{N}_{\mathrm{r}}$ compounds in different ecosystems}

The annual $\mathrm{NH}_{3}$ concentration showed significant spatial variation from alpine grassland to farmland in the Xinjiang arid region of central Asia. The highest $\mathrm{NH}_{3}$ concentration found was in farmland (YPH), which is affected by agricultural pollution sources. The lowest $\mathrm{NH}_{3}$ concentration was found in alpine grassland (BYB) where the absence of fertilizer applications and the lowest air temperatures may have contributed to lower $\mathrm{NH}_{3}$ volatilization and concentrations. Although agriculture is the main source of $\mathrm{NH}_{3}$, motor vehicles can be important sources of ammonia in urban environments (Ianniello et al., 2010). This may explain the moderate $\mathrm{NH}_{3}$ concentrations at the urban site (TFS). In the current study, annual $\mathrm{NO}_{2}$ concentrations also exhibited significant spatial variation. The highest $\mathrm{NO}_{2}$ concentration was found at an urban site (SDS) which is subject to anthropogenic pollution sources, and the lowest $\mathrm{NO}_{2}$ 

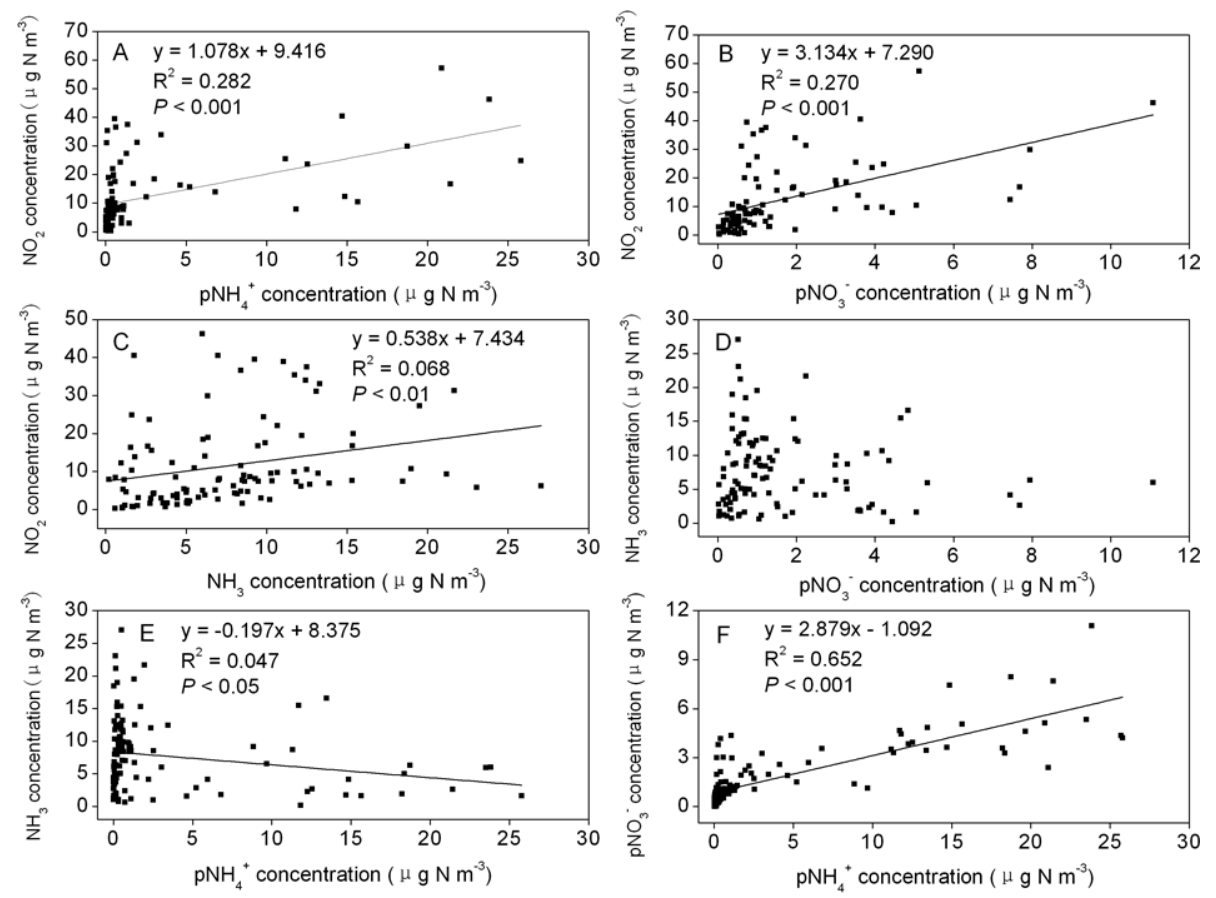

Fig. 5. Correlations among $\mathrm{NO}_{2}, \mathrm{NH}_{3}, p \mathrm{NO}_{3}^{-}$and $p \mathrm{NH}_{4}^{+}$concentrations. (A) $\mathrm{NO}_{2}$ vs. $p \mathrm{NH}_{4}^{+}$; (B) $\mathrm{NO}_{2}$ vs. $p \mathrm{NO}_{3}^{-}$; (C) $\mathrm{NO}_{2}$ vs. $\mathrm{NH}_{3}$; (D) $\mathrm{NH}_{3}$ vs. $p \mathrm{NO}_{3}^{-}$; (E) $\mathrm{NH}_{3}$ vs. $p \mathrm{NH}_{4}^{+}$; (F) $p \mathrm{NO}_{3}^{-}$vs. $p \mathrm{NH}_{4}^{+}$.

concentration was found in alpine grassland which is relatively undisturbed and free from anthropogenic activities. The highest $\mathrm{PM}_{10}$ concentrations were found in the desertoasis ecotone (CLZ) and desert (TZZ) in spring where sandstorm events often occur due to low precipitation and almost no vegetation cover, and the values were much higher than reported from numerous other sites (Kumar and Joseph, 2006; Li et al., 2006; Namdeo and Bell, 2005). Higher annual $p \mathrm{NH}_{4}^{+}$concentrations were found at sites SDS and TFS and were much higher than reported at many other urban and suburban sites (Hayashi et al., 2007), possibly due to anthropogenic influences. Higher annual $p \mathrm{NO}_{3}^{-}$concentrations were also found at SDS and TFS. We assume that Bayinbuluk alpine grassland (BYB, $3.09 \mu \mathrm{g} \mathrm{N} \mathrm{m}^{-3}$ ) is representative of background conditions, because it is remote from urban areas and relatively undisturbed by anthropogenic activities. Extremely high $\mathrm{N}_{\mathrm{r}}$ concentrations at an urban location (site SDS, $47.0 \mu \mathrm{g} \mathrm{N} \mathrm{m}^{-3}$ ) may reflect substantial air pollution due to increased emissions by traffic, industry and domestic heating, with consequent effects on the eutrophication of water bodies (Liu et al., 2011) and soil acidification in neighboring natural and semi-natural ecosystems (Yang et al., 2012). Yang et al. (2011) have pointed out that the arid desert region of northwest China is one of the main global sources of atmospheric dust, and the Taklimakan Desert in the Tarim Basin is an important source of sand/dust storms. Our results further demonstrate three types of air pollution by $\mathrm{N}_{\mathrm{r}}$ species: from natural sources (e.g. sand/dust storms due to dry weather conditions in the Taklimakan Desert region at CLZ, AKS, TZZ and YPH), from anthropogenic $\mathrm{N}_{\mathrm{r}}$ emissions (e.g. at arid suburban/urban locations such as TFS and SDS) and from combined natural and anthropogenic sources (e.g. at oasis/farmland locations such as TLF, FKZ and BTH). These differences require policy makers to formulate different strategies to control air pollution in the arid region of central Asia. Another implication is that the extent of air pollution of $\mathrm{N}_{\mathrm{r}}$ species at suburban and urban sites in Xinjiang is similar to or even greater than at intensively managed agricultural and industrial regions in China such as the North China Plain (Shen et al., 2011a, b). This may be due to the concentration of the human population and anthropogenic activities on the very limited oasis areas, which comprise only $5-6 \%$ of the total land area in Xinjiang.

\subsection{Seasonal variation in concentrations of $\mathrm{N}_{\mathrm{r}}$ compounds}

Higher $\mathrm{NH}_{3}$ concentrations were found in summer and autumn in farmland, most likely due to high $\mathrm{NH}_{3}$ emissions from $\mathrm{N}$ fertilizer applications, rapidly increasing livestock production, and motor vehicles. In contrast to other sites, summer $\mathrm{NH}_{3}$ concentrations were low in alpine grassland. This is most likely due to the transfer of almost all livestock to higher mountain areas (over $3000 \mathrm{~m}$ a.s.1.) and lower air temperatures. In north and northwest China, $\mathrm{NH}_{3}$ concentrations are relatively high in summer and autumn, mainly due to $\mathrm{N}$ fertilization and higher air temperatures, both of which 

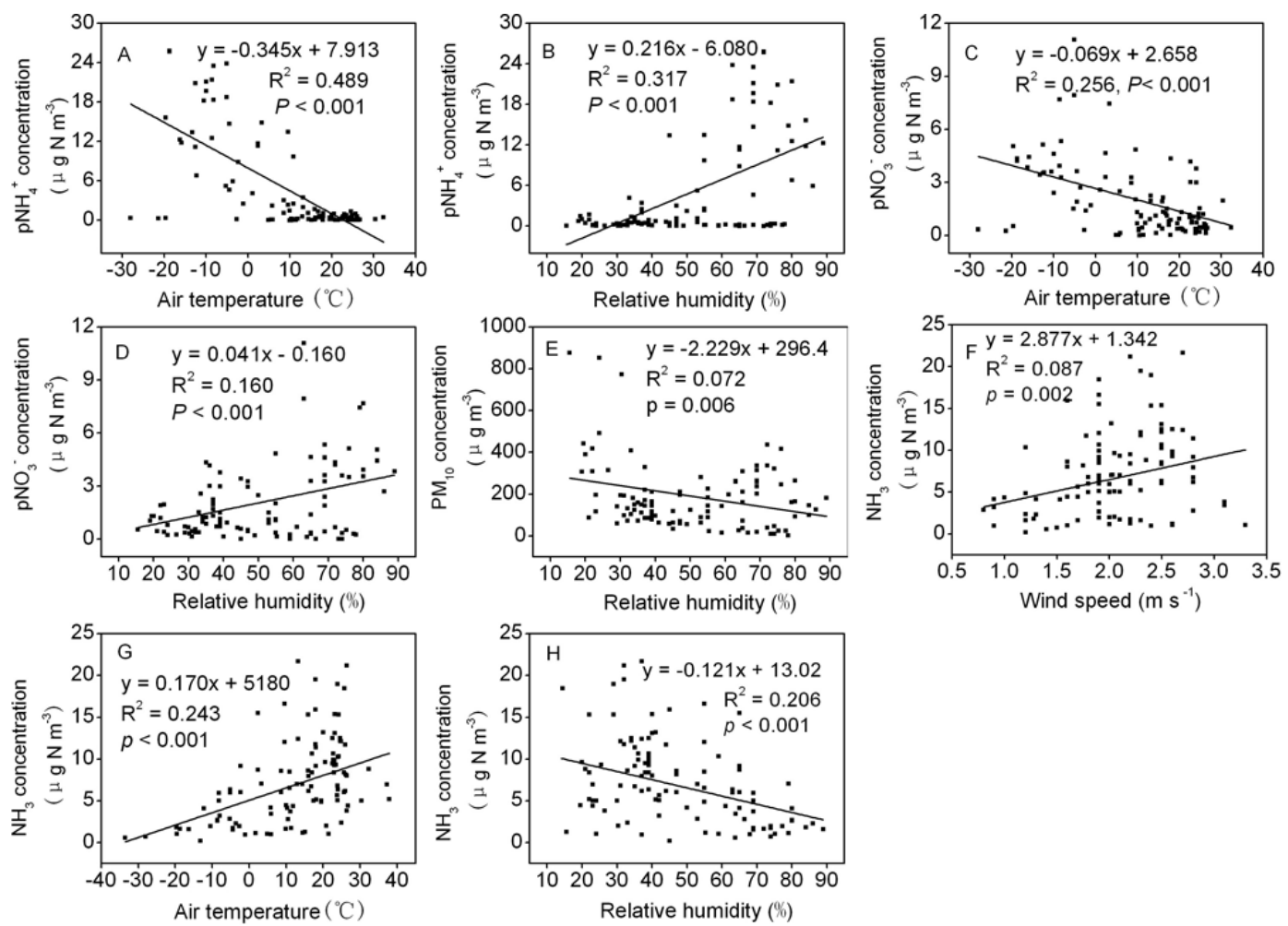

Fig. 6. Correlations among $p \mathrm{NH}_{4}^{+}, p \mathrm{NO}_{3}^{-}, \mathrm{PM}_{10}$ and $\mathrm{NH}_{3}$ concentrations and air temperature, relative humidity and wind speed. (A) $p \mathrm{NH}_{4}^{+}$ vs. air temperature; (B) $p \mathrm{NH}_{4}^{+}$vs. relative humidity; (C) $p \mathrm{NO}_{3}^{-}$vs. air temperature; (D) $p \mathrm{NO}_{3}^{-}$vs. relative humidity; (E) $\mathrm{PM} 10$ vs. relative humidity; (F) $\mathrm{NH}_{3}$ vs. wind speed; (G) $\mathrm{NH}_{3}$ vs. air temperature; (H) $\mathrm{NH}_{3}$ vs. relative humidity.

promote $\mathrm{NH}_{3}$ volatilization from arable soils. For example, the $\mathrm{N}$ fertilizer application rate can reach $240 \mathrm{~kg} \mathrm{~N} \mathrm{ha}^{-1}$ per crop to achieve high yields in spring and summer at site TFS. However, less than $30 \%$ of applied $\mathrm{N}$ fertilizer may be taken up by the crops (Zhang et al., 2008) and much of the unaccounted-for fertilizer $\mathrm{N}$ may have been lost by $\mathrm{NH}_{3}$ emission. Source strength and removal efficiency can explain seasonal variation in $\mathrm{NH}_{3}$ concentrations (Hong et al., 2002). Moreover, air temperature and wind speed determine the $\mathrm{NH}_{3}$ concentrations. Shen et al. (2011a) also reported the lowest seasonal $\mathrm{NH}_{3}$ concentration in winter at six sites on the North China Plain. $\mathrm{NO}_{2}$ concentrations exhibited distinct and significant seasonal variation, with higher concentrations in winter at almost all sites (except BYB), and reached their highest value at site SDS. These $\mathrm{NO}_{2}$ values were very similar to the high concentrations observed in other regions in China (Aas et al., 2007; Shen et al., 2009). Vehicle emissions and coal consumption for heating may be the main explanation for the higher $\mathrm{NO}_{2}$ concentrations. For example, Urumqi is only $140 \mathrm{~km}^{2}$ in area and had a population of 2.2 million and a total number of motor vehicles of 140000 units in 2003. However, motor vehicles reached 240000 units and were increasing at a rate of 260 units per day in 2009. Therefore, the higher $\mathrm{NO}_{2}$ concentrations are likely related to anthropogenic sources such as vehicle emissions at the urban site, and the use of coal for heating in north and northwest China in winter may be the main factor responsible for the increased $\mathrm{NO}_{\mathrm{x}}$ concentrations in the atmosphere. In addition, due to the paucity of rainfall or snowfall in winter in these arid areas, scavenging of atmospheric $\mathrm{NO}_{2}$ by wet deposition will be greatly limited. Higher $\mathrm{PM}_{10}$ concentrations in this study were found in spring and winter and were much higher than reported from numerous other sites (Kumar and Joseph, 2006; Li et al., 2006). We observed $\mathrm{PM}_{10}$ concentrations reaching maximum values due to dust storm events in spring, notably 852.7 and $876.2 \mu \mathrm{g} \mathrm{m}^{-3}$ at sites CLZ and TZZ, and they were even higher than in Lanzhou, a city with some of the highest air pollution worldwide with a peak $\mathrm{PM}_{10}$ concentration $\left(541.9 \mu \mathrm{g} \mathrm{m}^{-3}\right)$ occurring in April due to dust events (Wang et al., 2009). Higher PM $_{10}$ concentrations occurred in winter due to domestic heating. Moreover, increasing numbers of vehicles and low precipitation and relative humidity in the arid regions resulted in considerable $\mathrm{PM}_{10}$ pollution. The lowest $p \mathrm{NH}_{4}^{+}$concentrations were found in summer at almost all sites, while the highest $p \mathrm{NO}_{3}^{-}$concentrations were found in winter, especially at sites SDS, TFS and FKZ where the values were much higher than reported for numerous other sites (Hayashi et al., 2007). This was most likely generated from coal combustion in winter and from other anthropogenic sources such as vehicles, 
manufacturing and industrial processes at other times of year. Meteorological parameters such as low temperature and high relative humidity point towards poor dilution of pollutants during the winter period. Regarding the presence of nitrate associated with ammonium, it was more likely to form secondary particulate ammonium nitrate during periods of low temperatures and relatively high humidity in the arid areas.

\subsection{Ratios of concentrations of secondary particles to $\mathbf{P M}_{10}$}

Secondary particles $\left(p \mathrm{NH}_{4}^{+}\right.$and $\left.p \mathrm{NO}_{3}^{-}\right)$have been regarded as the main contributor to fine particulate matter (PM), which is harmful to human health and reduces visibility (Erisman and Schaap, 2004; Pinder and Adams, 2007) and is also implicated in climate change due to its effects on direct and indirect radiative forcing. In North China the ratios of secondary inorganic $\mathrm{N}$ particles to $\mathrm{PM}_{10}$ were relatively high. For example, concentrations of secondary particles $\left(p \mathrm{NH}_{4}^{+}\right.$ and $p \mathrm{NO}_{3}^{-}$) accounted for 14.6-22.3\% of the $\mathrm{PM}_{10}$ concentrations (Shen et al., 2011a). Heavy secondary particle pollution is a reflection of the high emission intensities of $\mathrm{NH}_{3}$ and $\mathrm{NO}_{\mathrm{x}}$ in north China. In our study, lower ratios were found in desert (TZZ, $0.35 \%$ ) and desert-oasis ecotone (CLZ, $0.63 \%$ ) sites, while farmland near a desert (FKZ, 13.6\%) and urban (SDS, $11.7 \%$ ) and suburban (TFS, $8.3 \%$ ) areas had higher ratios. The use of coal for heating may be a major factor because other sites (except BYB) have relatively high air temperatures with almost no coal consumption in winter. This indicates that anthropogenic activities have greatly increased the emissions of $\mathrm{N}_{\mathrm{r}}$ species and influenced local air pollution. Therefore, a decline in the concentration of secondary inorganic particles would be a worthwhile target to improve air quality in these arid regions. Further studies should focus on the fluxes of atmospheric $\mathrm{N}$ deposition and their ecological impacts along anthropogenic $\mathrm{N}_{\mathrm{r}}$ concentration gradients in the arid oasis Xinjiang region.

\section{Conclusions}

This study provides original monitoring data on spatial and temporal variations in atmospheric $\mathrm{N}_{\mathrm{r}}$ species and $\mathrm{PM}_{10}$ from an arid region of central Asia. Overall annual mean concentrations of $\mathrm{NH}_{3}, \mathrm{NO}_{2}, p \mathrm{NH}_{4}^{+}$and $p \mathrm{NO}_{3}^{-}$were 7.71, $9.68,1.81$ and $1.13 \mu \mathrm{g} \mathrm{N} \mathrm{m}^{-3}$, and the annual average $\mathrm{PM}_{10}$ concentration was $249.2 \mu^{-3} \mathrm{~g} \mathrm{~m}^{-3}$ in the Xinjiang arid region of northwest China. The increasing order of total concentrations of $\mathrm{N}_{\mathrm{r}}$ species was, respectively, alpine grassland; desert, desert-oasis ecotone; desert in an oasis; farmland; suburban and urban ecosystems. $\mathrm{NO}_{2}$ concentrations exhibited distinct and significant seasonal variation with higher concentrations in winter. Lower $p \mathrm{NH}_{4}^{+}$concentrations were found in summer at almost all sites, while the highest $p \mathrm{NO}_{3}^{-}$concentrations were found in winter. Lower ratios of secondary parti- cles $\left(\mathrm{NH}_{4}^{+}\right.$and $\left.\mathrm{NO}_{3}^{-}\right)$were found in desert and the desertoasis ecotone, while urban and suburban sites had higher ratios, indicating that anthropogenic activities such as home heating in winter have greatly influenced local air quality and pollution and requiring effective controlling measures.

Acknowledgements. This work was supported financially by the National Natural Science Foundation of China (Projects 41005001 and 41071151) and the "Hundred Talents Program" of the Chinese Academy of Sciences. We gratefully acknowledge Arvin Mosier and two reviewers for their constructive comments on an earlier version of the manuscript.

Edited by: A. R. Mosier

\section{References}

Aas, W., Shao, M., Jin, L., Larssen, T., Zhao, D. W., Xiang, R. J., Zhang, J. H., Xiao, J. S., and Duan, L.: Air concentrations and wet deposition of major inorganic ions at five non-urban sites in China, 2001-2003, Atmos. Environ., 41, 1706-1716, 2007.

Bai, Y. F., Wu, J. G., Clark, C. M., Naeem, S., Pan, Q. M., Huang, J. H., Zhang, L. X., and Han, X. G.: Tradeoffs and thresholds in the effects of nitrogen addition on biodiversity and ecosystem functioning: Evidence from inner Mongolia Grasslands, Global Change Biol., 16, 358-372, 2010.

Chan, C. K. and Yao, X. H.: Air pollution in mega cities in China, Atmos. Environ., 42, 1-42, 2008.

Clark, C. M. and Tilman, D.: Loss of plant species after chronic low-level nitrogen deposition to prairie grasslands, Nature, 451 , 712-715, 2008.

Erisman, J. W. and Schaap, M.: The need for ammonia abatement with respect to secondary PM reductions in Europe, Environ. Pollut., 129, 159-163, 2004

Galloway, J. N., Townsend, A. R., Erisman, J. W., Bekunda, M., Cai, Z. C., Freney, J. R., Martinelli, L. A., Seitzinger, S. P., and Sutton, M. A.: Transformation of the nitrogen cycle: recent trends, questions, and potential solutions, Science, 320, 889-892, 2008

Guo, J. H., Liu, X. J., Zhang, Y., Shen, J. L., Han, W. X., Zhang, W. F., Christie, P., Goulding, K. W. T., Vitousek, P. M., and Zhang, F S.: Significant acidification in major Chinese croplands, Science, 327, 1008-1010, 2010.

Hayashi, K., Komada, M., and Miyata, A.: Atmospheric deposition of reactive nitrogen on turf grassland in central Japan: comparison of the contribution of wet and dry deposition, Water. Air. Soil. Poll., 7, 119-129, 2007.

Hong, Y. M., Lee, B. K., Park, K. J., Kang, M. H., Jung, Y. R., Lee, D. S., and Kim, M. G.: Atmospheric nitrogen and sulfur containing compounds for three sites of South Korea. Atmos. Environ., 36, 3485-3494, 2002.

Ianniello, A., Spataro, F., Esposito, G., Allegrini, I., Rantica, E., Ancora, M. P., Hu, M., and Zhu, T.: Occurrence of gas phase ammonia in the area of Beijing (China), Atmos. Chem. Phys., 10, 9487-9503, doi:10.5194/acp-10-9487-2010, 2010.

Kulshrestha, A., Satsangi, P. G., Masih, J., and Taneja, A.: Metal concentration of $\mathrm{PM}_{2.5}$ and $\mathrm{PM}_{10}$ particles and seasonal variations in urban and rural environment of Agra, India, Sci. Total Environ., 407, 6196-6204, 2009. 
Kumar, R. and Joseph, A.E.: Air pollution concentrations of $\mathrm{PM}_{2.5}$, $\mathrm{PM}_{10}$ and $\mathrm{NO}_{2}$ at ambient and kerbsite and their correlation in Metro City - Mumbai, Environ. Monit. Assess., 119, 191-199, 2006.

Li, J., Zhuang, G. S., Huang, K., Lin, Y. F., Xu, C., and Yu, S. L.: Characteristics and sources of air-borne particulate in Urumqi, China, the upstream area of Asia dust, Atmos. Environ., 42, 776787, 2008.

Li, K. H., Gong, Y. M., Song, W., He, G. X., Hu, Y. K., Tian, C. Y., and Liu, X. J.: Responses of $\mathrm{CH}_{4}, \mathrm{CO}_{2}$ and $\mathrm{N}_{2} \mathrm{O}$ fluxes to increasing nitrogen deposition in alpine grassland of the Tianshan Mountains, Chemosphere, 88, 140-143, 2012a.

Li, K. H., Gong, Y. M., Song, W., Lv, J. L., Chang, Y. H., Hu, Y. K., Tian, C. Y., Christie, P., and Liu, X. J.: No significant nitrous oxide emissions during spring thaw under grazing and nitrogen fertilization in an alpine grassland, Glob. Change Biol., 18, 2546-2554, 2012b.

Li, T. T., Bai, Y. H., Liu, Z. R., Liu, J. F., Zhang, G. S., and Li, J. L.: Air quality in passenger cars of the ground railway transit system in Beijing, China, Sci. Total Environ., 367, 89-95, 2006.

Liu, X. J., Song, L., He, C. E., and Zhang, F. S.: Nitrogen deposition as an important nutrient from the environment and its impact on ecosystems in China, J. Arid Land, 2, 137-143, 2010.

Liu, X. J., Duan, L., Mo, J. M., Du, E. Z., Shen, J. L., Lu, X. K., Zhang, Y., Zhou, X. B., He, C. E., and Zhang, F. S.: Nitrogen deposition and its ecological impact in China: an overview, Environ. Pollut., 159, 2251-2264, 2011.

Mamtimin, B. and Meixner, F. X.: Air pollution and meteorological processes in the growing dryland city of Urumqi (Xinjiang, China), Sci. Total Environ., 409, 1277-1290, 2011.

Namdeo, A. and Bell, M. C.: Characteristics and health implications of fine and coarse particulates at roadside, urban background and rural sites in UK, Environ. Int., 31, 565-573, 2005.

Phoenix, G. K., Hicks, W. K., Cinderby, S., Kuylenstierna, J. C. I., Stock, W. D., Dentener, F. J., Giller, K. E., Austin, A. T., Lefroy, R. D. B., Gimeno, B. S., Ashmore, M. R., and Ineson, P.: Atmospheric nitrogen deposition in world biodiversity hotspots: The need for a greater global perspective in assessing $\mathrm{N}$ deposition impacts, Global Change Biol., 12, 470-476, 2006.

Pinder, R. W., Adams, P. J., and Pandis, S. N.: Ammonia emission controls as a cost-effective strategy for reducing atmospheric particulate matter in the eastern United States, Environ. Sci. Technol., 41, 380-386, 2007.

Shen, J. L., Tang, A. H., Liu, X. J., Fangmeier, A., Goulding, K. T. W., and Zhang, F. S.: High concentrations and dry deposition of reactive nitrogen species at two sites in the North China Plain, Environ. Pollut., 157, 3106-3113, 2009.
Shen, J. L., Liu, X. J., Fangmeier, A., Goulding, K., and Zhang, F. S.: Atmospheric ammonia and particulate ammonium from agricultural sources in the North China Plain, Atmos. Environ., 45, 5033-5041, 2011a.

Shen, J. L., Tang, A. H., Liu, X. J., Kopsch, J., Fangmeier, A., Goulding, K., and Zhang, F. S.: Impacts of pollution controls on air quality in Beijing during the 2008 Olympic Games, J. Environ. Qual., 40, 37-45, 2011 b.

Sutton, M. A., Howard, C. M., Erisman, J. W., Billen, G., Bleeker, A., Grennfelt, P., Grinsven, H. V., and Grizzetti, B.: The European Nitrogen Assessment: Sources, Effects and Policy Perspectives, Cambridge University Press, London, 2011.

Song, L., Bao, X., Liu, X., Zhang, Y., Christie, P., Fangmeier, A., and Zhang, F.: Nitrogen enrichment enhances the dominance of grasses over forbs in a temperate steppe ecosystem, Biogeosciences, 8, 2341-2350, doi:10.5194/bg-8-2341-2011, 2011.

Song, L., Bao, X. M., Liu, X. J., and Zhang, F. S.: Impact of nitrogen addition on plant community in a semi-arid temperate steppe in China, J. Arid Land, 4, 3-10, 2012.

Tang, L. S., Li, Y., and Zhang, J. H.: Partial rootzone irrigation increases water use efficiency, maintains yield and enhances economic profit of cotton in arid area, Agr. Water Manage., 97, 1527-1533, 2010.

Vitousek, P. M., Aber, J. D., Howarth, R. W., Likens, G. E., Matson, P. A., Schindler, D. W., Schlesinger, W. H., and Tilman, G. D.: Human alteration of the global nitrogen cycle: Sources and consequences, Ecol. Appl., 7, 737-750, 1997.

Wang, S. G., Feng, X. Y., Zeng, X. Q., Ma, Y. X., and Shang, K. Z.: A study on variations of concentrations of particulate matter with different sizes in Lanzhou, China, Atmos. Environ., 43, 28232828, 2009.

Yang, X. H., Xu, X. L., Qing, H., Mamtimin, A., Yu, B., and Tang, S. H.: Sand flux estimation during a sand-dust storm at Tazhong area of Taklimakan Desert, China, J. Arid Land., 3, 199-205, 2011.

Yang, Y. H., Ji, C. J., Ma, W. H., Wang, S. F., Wang, S. P., Han, W. X., Mohammat, A., Robinson, D., and Smith, P.: Significant soil acidification across northern China's grasslands during 1980s2000s, Global Change Biol., 18, 2292-2300, 2012.

Zhang, F. S., Wang, J. Q., Zhang, W. F., Cui, Z. L., Ma, W. Q., Chen, X. P., and Jiang, R. F.: Nutrient use efficiency of major cereal crops in China and measures for improvement, Acta Pedol. Sin., 45, 915-924, 2008 (in Chinese with English abstract). 